\title{
EFEKTIVITAS ARANG AKTIF DIPERKAYA MIKROBA KONSORSIA TERHADAP RESIDU INSEKTISIDA LINDAN DAN ALDRIN DI LAHAN SAYURAN
}

\section{EFFECTIVENESS OF ACTIVATED CARBON ENRICHED CONSORSIA MICROBES ON INSECTICIDAL RESIDUES OF LINDANE AND ALDRIN IN VEGETABLE LAND}

\author{
E.Srihayu Harsanti, Indratin, Sri Wahyuni, Eman Sulaeman, dan A.N. Ardiwinata
}

(Diterima tanggal 30-04-2012; Disetujui tanggal 2-11-2012)

\begin{abstract}
ABSTRAK
Lindan dan aldrin merupakan insektisida organoklorin yang residunya masih ditemukan di lahan sayuran. Lindan dan aldrin merupakan senyawa cemaran organic persisten (Persistent Organic Pollutants atau POPs) yang memiliki toksisitas dan persistensi yang tinggi di dalam tanah. Salah satu mitigasi residu insektisida POPs dalam tanah adalah remediasi dengan menggunakan arang aktif dengan memanfaatkan mikroba konsorsia. Percobaan lapang dilaksanakan di lahan sayuran di Magelang selama musim penghujan 2010. Tujuan penelitian adalah mengetahui efektivitas arang aktif diperkaya mikroba konsorsia terhadap degradasi residu lindan dan aldrin di lahan sayuran. Percobaan lapang disusun menggunakan rancangan acak kelompok dengan tiga ulangan dan tujuh perlakuan. Parameter yang diamati yaitu karakteristik tanah, residu insektisida lindan dan aldrin dalam tanah dan air, tinggi dan hasil biomassa sawi. Arang aktif efektif menurunkan residu lindan dan aldrin dalam tanah hingga lebih dari $50 \%$ saat 7 hari setelah aplikasi insektisida pada tanaman sawi. Arang aktif yang diperkaya mikroba konsorsia cennderung menurunkan residu lindan dan aldrin lebih tinggi daripada arang aktif tanpa diperkaya mikroba konsorsia. Kadar pestisida lindan dan aldrin dalam tanaman pada perlakuan arang aktif dari tempurung kelapa lebih tinggi daripada arang aktif tongkol jagung dengan inokulasi mikroba. Pemberian arang aktif cenderung memberikan hasil biomassa tanaman sawi lebih tinggi daripada tanpa arang aktif.
\end{abstract}

Kata kunci: arang aktif, mikroba konsorsia, lindan, aldrin, sawi

\begin{abstract}
Lindane and aldrin are organochlorine insecticides that their residues are still found in vegetables lands. Lindane and aldrin are included as persistent organic pollutants (POPS) with high toxicity and persistant in the soil. One of the mitigations of insecticide residues of POPs in soils is remediation by using activated charcoal and consortia microbes. Field experiment was conducted in the vegetables centre in Magelang during the rainy season of 2010. The objective is to examine the effectiveness of activated charcoal enriched consortia microbes on degradation of lindane and aldrin residues in vegetable fields. A randomized block design with three replications and seven treatments was used in the experiment. The observed parameters were soil characteristics, residues of lindane and aldrin in soil and water, cabbage biomass. Activated charcoal effectively reduced residues of lindane and aldrin in the soil by more than $50 \%$ at 7 days after application of insecticides on cabbage crop. Activated charcoal enriched consortia microbe tends to reduce residues of lindane and aldrin higher than activated charcoal without enriched consortia microbes. Residues of lindane and aldrin in plot treated with activated charcoal from coconut shell was higher than in plot treated with activated charcoal from corn cobs with microbial inoculation. Application of activated charcoal tends gave cabbage biomass yield higher than without applying active charcoal.
\end{abstract}

Keywords: activated charcoal, consortia microbes, lindane, aldrin, cabbage 


\section{PENDAHULUAN}

Pestisida merupakan salah satu komponen pengendalian organisme pengganggu tanaman yang paling banyak digunakan di tingkat petani. Penggunaan pestisida makin intensif dan cenderung tidak terkontrol dalam budidaya tanaman sayuran, yang dapat berdampak negatif terhadap agroekologi pertanian dan kesehatan manusia. Hingga kini residu organoklorin masih banyak ditemukan di lahan pertanian termasuk lahan sayuran. Meskipun penggunaan insektisida organoklorin telah dilarang, namun keberadaannya di dalam tanah, produk, dan di pasaran masih sering dijumpai. Insektisida organoklorin umumnya memilki toksisitas tinggi dan persistensi lama dalam tanah sehingga berpotensi mencemari lingkungan. Insektisida organoklorin yang digunakan relatif intensif di lahan sayuran adalah lindan dan aldrin. Insektisida organoklorin umumnya mengandung senyawa Persistent Organic Pollutants (POPs).

Di antara opsi mitigasi residu insektisida senyawa POPs adalah remediasi dengan dan mikroba konsorsia. Arang aktif adalah bahan berkarbon yang berstuktur sarang sangat baik dengan luas permukaan spesifik internal besar yang mampu menambat molekul-molekul beragam pada permukaan inner, dan mampu menjerap berbagai bahan baik dalam bentuk fase gas ataupun cair. Arang aktif terdiri atas 87-97 \% C dan mengandung unsur-unsur seperti oksigen, hidrogen, sulfur, dan nitrogen (1). Arang aktif dari limbah-limbah pertanian merupakan tempat ideal yang menguntungkan bagi mikroba (microhabitat) antara lain mikroba pendegradasi insektisida. Arang aktif mengurangi ketersediaan kontaminan organic secara jitu dalam tanah karena kuatnya sifat jerapan (2). Pembenah arang aktif lebih disukai daripada remediasi lainnya karena ramah lingkungan, tidak melepaskan cemaran baru, dan efektif. Tanah yang ditambahkan arang aktif dapat meningkatkan populasi mikroba yang ditengarai berperan dalam proses degradasi residu pestisida (3).

Dekomposisi pestisida secara hayati adalah salah satu cara efektif untuk memindahkan senyawa POP dari lingkungan. Di antara komunitas mikroba, bakteri, fungi, aktinomicetes adalah transformer dan degrader utama senyawa pestisida. Bakteri Bacillus thioxidans dan Speudomonas paucimobilis dapat mendegradasi lindan setelah inkubasi secara aerobik selama tiga hari (4). Bakteri gram positifAktinomicetes berpotensi sebagai biotransformasi dan biodegradasi pestisida organoklorin, organofosfat, dan karbamat (5). Kemampuan arang aktif sebagai pendegradasi senyawa POPs dapat ditingkatkan dengan memanfaatkan mikroba tertentu (2), baik dengan cara inokulasi ataupun diintegrasikan ke dalam arang aktif. Penelitian dilaksanakan untuk mengetahui efektivitas arang aktif yang diperkaya dengan mikroba konsorsia terhadap residu insektisida lindan dan aldrin di lahan sayuran.

\section{BAHAN DAN METODE}

Percobaan lapang dilaksanakan di sentra sayuran Magelang Jawa Tengah selama musim penghujan 2010, yaitu di Desa Sukomakmur Kec. Kajoran. Jenis tanah lokasi percobaan adalah Andisol dengan kelas tekstur lempung berliat (37\% pasir, 32\% debu, 31\% liat, $\mathrm{pH}$ agak masam $(5,43), \mathrm{P}$ tersedia rendah $(8,03$ 
ppm P), KTK tinggi (30,3 cmol/kg), C organik sedang $(2,12 \%)$, dan tanah mengandung alofan dengan $\mathrm{pH}(\mathrm{NaF})>10$.

Bahan yang digunakan dalam penelitian antara lain adalah arang aktif sebagai selaput pupuk urea (urea coated activated charcoal), pupuk SP36, pupuk $\mathrm{KCl}$, benih sawi, bahan penunjang di lapangan, dan bahan penunjang di laboratorium seperti akuades, dan bahan khemikhalia lainnya. Peralatan yang digunakan selama penelitian antara lain adalah kromatografi gas yang dilengkapi dengan detector ECD, rotary evaporator, sokhlet, neraca analitik, penggojog, dan lainnya.

Percobaan lapang disusun menggunakan rancangan acak kelompok, diulang 3 kali dengan 7 perlakuan sebagai berikut :

1. Kontrol (tanpa arang aktif) $\left(\mathrm{U}_{0}\right)$

2. Arang aktif tempurung kelapa $\left(\mathrm{U}_{1}\right)$

3. Arang aktif tongkol jagung $\left(\mathrm{U}_{2}\right)$

4. Arang aktif tempurung kelapa diperkaya mikroba konsorsia $\left(\mathrm{U}_{3}\right)$

5. Arang aktif tongkol jagung diperkaya mikroba konsorsia $\left(\mathrm{U}_{4}\right)$

6. Arang aktif tempurung kelapa + mikroba konsorsia $\left(\mathrm{U}_{5}\right)$

7. Arang aktif tongkol jagung + mikroba konsorsia $\left(\mathrm{U}_{6}\right)$

Perlakuan arang aktif merupakan arang aktif yang digunakan sebagai pelapis pupuk urea dengan perbandingan 80 (urea) : 20 (arang aktif). Mikroba konsorsia yang antara lain mengandung bakteri dari genus Bacillus, Pseudomonas, Azospirillum, dan genus jamur Trichoderma digunakan untuk memperkaya arang aktif dengan cara disemprotkan ke dalam arang aktif, sedangkan mikroba konsorsia yang diinokulasikan diberikan bersamaan dengan aplikasi arang aktif ke dalam tanah dan pemberiannya terpisah dengan aplikasi arang aktif.

Sawi sebagai tanaman indikator ditanam dengan jarak tanam $40 \mathrm{~cm}$ x $20 \mathrm{~cm}$ pada plot yang berukuran $2 \mathrm{~m}$ x $4 \mathrm{~m}$. Pupuk N, P, $\mathrm{K}$ dengan takaran $100 \mathrm{~kg} \mathrm{~N}, 45 \mathrm{~kg} \mathrm{P}_{2} \mathrm{O}_{5}, 60$ $\mathrm{kg} \mathrm{K}_{2} \mathrm{O}$ per hektar diberikan sesuai anjuran, dimana pupuk $\mathrm{N}$ diberikan dua tahap yaitu saat tanam dan awal pembentukan crop. Pupuk $\mathrm{P}$ dan $\mathrm{K}$ diberikan sekaligus saat tanam. Ke dalam masing-masing petakan diaplikasikan insektisida organoklorin (lindan dan aldrin) dengan kadar 5 ppm.

Parameter yang diamati yaitu kadar residu lindan dan aldrin dalam tanah, air, dan tanaman sawi, tinggi tanaman, jumlah daun, lebar kanopi, dan bobot biomassa tanaman. Tinggi tanaman, jumlah daun, dan lebar kanopi diamati saat 7 hari setelah aplikasi dan 21 hari setelah tanam. Bobot biomassa sawi diamati saat panen. Pengamatan kadar residu lindan dan aldrin dalam tanah dilakukan pada saat 7 hari setelah aplikasi insektisida (hsa) dan 21 hari setelah tumbuh (hst), sedangkan kadar lindan dan aldrin dalam air diamati satu dan 7 hari setelah aplikasi (hsa). Kadar lindan dan aldrin pada tanaman diamati saat panen.

Analisis penetapan residu lindan dan aldrin meliputi ekstraksi, clean up, analisis kromatografi (6). Prosedur ekstraksi dilakukan dengan menimbang 25 gram cuplikan (tanah yang telah dihaluskan), dimasukkan ke dalam erlenmeyer bertutup basah, dan ditambahkan campuran aseton : diklormetana $(50: 50, \mathrm{v} / \mathrm{v})$, dibiarkan selama satu malam untuk proses ekstraksi statis.

Hasil ekstraksi disaring dengan Buchner 
yang diberi celite. Pipet $25 \mathrm{ml}$ fase organik ke dalam labu bulat, dipekatkan dalam rotavapor pada suhu tangas air $40^{\circ} \mathrm{C}$ sampai hampir kering dan dikeringkan dengan mengalirkan gas nitrogen sampai kering, diikuti dengan pembersihan (clean up). Residu dalam $5 \mathrm{~mL}$ dilarutkan dengan petroleum eter dan uapkan kembali hingga kering. Residu dilarutkan dalam 1,0 mL petroleum eter $40^{\circ} \mathrm{C}-60^{\circ} \mathrm{C}$ sehingga larutan mengandung 2,0 gram cuplikan analitik per $\mathrm{mL}$.

Sebanyak 1,0 gram alumina berlapis perak nitrat dimasukkan kedalam kolom kromatograf yang telah diberi wol kaca, ditambahkan $1 \mathrm{~mL}$ ekstrak yang mengandung 2 gram cuplikan analitik per $\mathrm{mL}$ kedalam kolom dan dibilas bagian dalam dinding kolom dengan $1 \mathrm{~mL}$ eluen campuran. Elusi dengan $9 \mathrm{~mL}$ eluen campuran yang sama.

Eluat ditampung ke dalam tabung berskala dan pekatkan sampai $1 \mathrm{~mL}$, dan residunya dilarutkan dalam $5 \mathrm{ml}$ isooktana : toluena (90: 10, v/v). Penetapan kadar residu dengan menyuntikan $1 \mu \mathrm{L}$ ekstrak ke dalam kromatografi gas. Waktu tambat dan tinggi atau luas puncak kromatogram yang diperoleh dari larutan cuplikan dibandingkan dengan larutan baku pembanding. Nilai perolehan kembali $>80 \%$ dan batas penetapan $0,01-0,5 \mathrm{mg} / \mathrm{kg}$.

Residu yang terdapat dalam contoh dihitung berdasarkan rumus:

$$
\text { Residu }=\mathrm{Ks} \times \frac{\mathrm{Ac} \times \mathrm{Vic} \times \mathrm{Vfc}}{\mathrm{As} \times \mathrm{Vis} \times \mathrm{B} \times \mathrm{R}}
$$

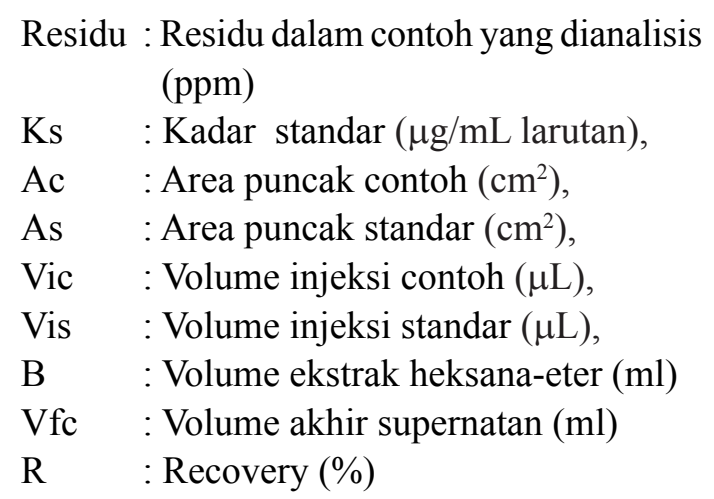

Data dianalisis dengan sidik ragam menggunakan program SAS (Statistical Analysis System) versi 8.0, dan dilanjutkan dengan uji duncan (DMRT) untuk mengetahui pengaruh antar perlakuan.

\section{HASIL DAN PEMBAHASAN}

\section{Residu Insektisida POPs}

Analisis pendahuluan contoh tanah di lokasi percobaan menunjukkan bahwa beberapa pestisida golongan organoklorin yang merupakan senyawa POP terdeteksi dalam contoh tanah, antara lain : endosulfan $(0,004$ ppm), lindan (0,0033 ppm), heptaklor $(0,0019$ $0,0033 \mathrm{ppm})$, DDT (0,0034 ppm), endrin (0,0019-0,0032 ppm), dan dieldrin (0,0097$0,0121 \mathrm{ppm}$ ) yang kadarnya telah mendekati nilai ADI (Aceptable Daily Intake) (Tabel 1). Kisaran residu organoklorin yang ditemukan di lahan sayuran Kajoran Kab. Magelang masih lebih rendah daripada batas maksimum residu terutama lindan (0,5 ppm) (7). Perilaku POPs dalam tanah dipengaruhi oleh komponen esensial tanah antara lain \% $\mathrm{C}$ organik, \% liat, pH tanah, KTK, dan kadar air tanah (8). Penurunan kadar residu POP dalam tanah dipengaruhi oleh sifat atau karakteristik POPs, kelarutan dalam air, kandungan bahan 
Tabel 1. Kadar residu insektisida POPs yang terdeteksi di lahan sayuran Ds. Sukomakmur, Kec. Kajoran, Kab. Magelang. 2010

\begin{tabular}{|l|c|c|}
\hline Jenis insektisida POPs & Kisaran kadar terdeteksi $(\mathrm{ppm})$ & $\begin{array}{c}\left.\text { Nilai ADI }{ }^{*}\right) \\
(\text { Aceptable Daily Intake) }\end{array}$ \\
\hline Endosulfan & $0-0,004$ & 0,0080 \\
Lindan & $0-0,0033$ & 0,0080 \\
Heptaklor & $0,0019-0,0033$ & 0,0005 \\
DDT & $0-0,0034$ & 0,0020 \\
Endrin & $0,0019-0,0032$ & - \\
Dieldrin & $0,0097-0,0121$ & 0,0001 \\
\hline
\end{tabular}

Ket: *) FAO dan WHO (1998); - tidak terdeteksi

organik tanah dan liat. Beberapa POPs yang terikat kuat pada tanah yang berbahan organik tinggi, antara lain DDT, klordan, lindan, dan aldrin (8). DDT ditambat dalam tanah dan fraksi tanah atau liat dengan proporsi lebih tinggi dari bahan organik tanah, selain itu tingkat kelarutan dalam air relatif rendah menyebabkan proses degradasi umumnya berjalan sangat lambat (9).

Pemberian arang aktif tidak nyata mempengaruhi kadar residu lindan dalam air saat $1 \mathrm{hst}$, tetapi nyata pada saat $7 \mathrm{hst}$ (p $\leq$ 0,0007). Kadar residu lindan saat 1 dan 7 hsa relatif kecil dan pemanfaatan mikroba konsorsia cenderung menurunkan residu lindan dalam air (Tabel 2). Pada Tabel 2 terlihat bahwa pemberian arang aktif nyata menjerap insektisida lindan dalam tanah, dengan peluang $p \leq 0,0419$ saat 7 hsa dan $p$ $\leq 0,0001$ saat 21 hst. Dari 5 ppm lindan yang aplikasikan, residu linden yang terakumulasi dalam tanah saat 7 hsa berkisar 3,3-9,8\%. Saat $7 \mathrm{hsa}$, kadar residu lindan terendah dalam tanah ditemukan pada perlakuan arang aktif tongkol jagung $(0,1665$ ppm), sebaliknya kadar residu lindan tertinggi ditemukan pada pelakuan arang aktif tempurung kelapa diperkaya mikroba konsorsia (0,49 ppm). Residu lindan dalam tanah mengalami penurunan sebesar
26-91\% saat 21 hst. Penurunan kadar residu lindan tertinggi ditemukan pada perlakuan arang aktif tempurung kelapa diperkaya mikroba konsorsia, sedangkan penurunan residu terendah ditemukan pada perlakuan arang aktif tongkol jagung. Saat $21 \mathrm{hst}$, arang aktif yang diperkaya mikroba konsorsia ataupun diinokulasi mikroba konsorsia efektif menurunkan residu lindan dalam tanah. Hasil penelitian di Jepang menunjukan bahwa arang aktif diperkaya mikroba konsorsia dapat meminimalkan cemaran simazine pada tanah bawahan (subsoil), air sungai, dan air tanah selama beberapa tahun (2).

Saat 21 hst, arang aktif yang diperkaya mikroba konsorsia ataupun diinokulasi mikroba konsorsia efektif menurunkan residu lindan dalam tanah. Pemberian arang aktif tidak nyata mempengaruhi kadar residu lindan dalam air saat $1 \mathrm{hst}$, tetapi nyata pada saat 7 hst $(\mathrm{p} \leq 0,0007)$. Kadar residu lindan saat 1 dan 7 hsa relatif kecil dan pemanfaatan mikroba konsorsia cenderung menurunkan residu lindan dalam air.

Pembenah arang aktif hanya nyata memperngaruhi residu aldrin dalam tanah saat 21 hst $(\mathrm{p} \leq 0,0581)$ dan dalam air saat 7 hst ( $\mathrm{p} \leq$ $0,0147)$. Dari 5 ppm aldrin yang diaplikasikan, tanah mampu menjerap residu aldrin sekitar 
Tabel 2. Kadar residu lindan dalam tanah dan air pada tanaman sawi di Magelang, tahun 2010

\begin{tabular}{|c|c|c|c|c|}
\hline \multirow{2}{*}{ Perlakuan } & \multicolumn{4}{|c|}{ Kadar residu lindan (ppm) } \\
\cline { 2 - 5 } & \multicolumn{2}{|c|}{ Tanah } & 1 hsa & 7 hsa \\
\cline { 2 - 5 } & 7 hst & 21 hst & $0,0020 \mathrm{a}$ & $0,0040 \mathrm{~b}$ \\
U0 & $0,2870 \mathrm{bc}$ & $0,1130 \mathrm{~b}$ & $0,0050 \mathrm{a}$ & $0,0075 \mathrm{a}$ \\
U1 & $0,3690 \mathrm{ab}$ & $0,1505 \mathrm{a}$ & $0,0065 \mathrm{a}$ & $0,0025 \mathrm{bc}$ \\
U2 & $0,1665 \mathrm{c}$ & $0,1235 \mathrm{~b}$ & $0,0025 \mathrm{a}$ & $0,0025 \mathrm{bc}$ \\
U3 & $0,4900 \mathrm{a}$ & $0,0455 \mathrm{c}$ & $0,0015 \mathrm{a}$ & $0,0015 \mathrm{c}$ \\
U4 & $0,3460 \mathrm{ab}$ & $0,0520 \mathrm{c}$ & $0,0010 \mathrm{a}$ & $0,0015 \mathrm{c}$ \\
U5 & $0,2425 \mathrm{bc}$ & $0,0295 \mathrm{c}$ & $0,0025 \mathrm{a}$ & $0,0020 \mathrm{c}$ \\
U6 & $0,2680 \mathrm{bc}$ & $0,0445 \mathrm{c}$ & 0 \\
\hline
\end{tabular}

Angka dalam lajur diikuti huruf sama tidak berbeda nyata pada taraf 5\% menurut uji DMRT,

hsa $=$ hari setelah aplikasi insektisida, hst $=$ hari setelah tumbuh

Keterangan : $\mathrm{U} 0=$ tanpa arang aktif, $\mathrm{U} 1=$ arang aktif tempurung kelapa $\mathrm{U} 2=$ arang aktif tongkol jagung, $\mathrm{U} 3=$ arang aktif tempurung kelapa diperkaya mikroba konsorsia, , U4 = arang aktif tongkol jagung diperkaya mikroba konsorsia U5 = arang aktif tempurung kelapa + mikroba U6 = arang aktif tongkol jagung + mikroba konsorsia

4,1-17,0\%. Tanah tanpa arang aktif menjerap aldrin lebih tinggi daripada dengan pemberian arang aktif, yaitu 17,0\% saat 7 hsa (Tabel 3). Saat 21 hst, residu aldrin dalam tanah turun sekitar $40-95 \%$ dengan pemberian arang aktif. Penurunan residu aldrin tertinggi ditemukan pada perlakuan arang aktif tongkol jagung + mikroba konsorsia, sedangkan penurunan residu aldrin dalam tanah terendah ditemukan pada perlakuan arang aktif tempurung kelapa. Pemanfaatan mikroba konsorsia untuk memperkaya arang aktif atau diinokulasikan ke dalam tanah menurunkan residu aldrin secara nyata saat 21 hst (Tabel 3). Residu aldrin dalam air cenderung meningkat pada saat 7 hsa, dan residu aldrin dalam air tampak lebih rendah dengan peanfaatan mikroba konsorsia.

Pengkayaan mikroba konsorsia ke dalam arang aktif pada tanaman sayuran sawi cenderung menurunkan residu aldrin dan lindan lebih besar daripada tanpa inokulasi mikroba konsorsia. Rongga arang aktif memberikan tempat ideal bagi mikroba pendegradasi senyawa POPs sehingga dapat menurunkan kadar POPs melalui proses detoksitas dan degradasi (9). Tanpa peran mikroba, pestisida dan hasil degradasinya akan terangkut ke dalam jaringan tanaman yang dikonsumsi manusia dalam jumlah yang relatif lebih tinggi daripada dengan melibatkan mikroba pendegradasi pestisida (3).

Gambar 2 memperlihatkan residu lindan dan aldrin dalam tanaman sawi. Kadar residu lindan dalam tanaman sawi rata-rata lebih tinggi 0,1 ppm, sedangkan kadar residu aldrin rata-rata kurang dari $0,1 \mathrm{ppm}$. Kadar lindan dan aldrin dalam tanaman sawi berkisar 21582 ppb (lindan) dan 18-204 ppb (aldrin). Arang aktif umumnya menurunkan serapan insektisida lindan dan aldrin oleh akar tanaman sawi. Kadar residu lindan dalam tanaman pada perlakuan arang aktif dari tempurung kelapa + mikroba konsorsia adalah lebih tinggi daripada perlakuan arang aktif lainnya. Perlakuan arang aktif diperkaya mikroba cenderung menurunkan residu pestisida lindan dan aldrin dalam tanaman lebih tinggi daripada perlakuan arang aktif + mikroba konsorsia. Pada inokulasi mikroba konsorsia, kadar 
Tabel 3. Kadar residu aldrin dalam tanah dan air pada tanaman sawi di Magelang, tahun 2010

\begin{tabular}{|c|c|c|c|c|}
\hline \multirow{3}{*}{ Perlakuan } & \multicolumn{4}{|c|}{ Kadar residu aldrin (ppm) } \\
\hline & \multicolumn{2}{|c|}{ Tanah } & \multicolumn{2}{|c|}{ Air } \\
\hline & $7 \mathrm{hsa}$ & $21 \mathrm{hst}$ & $1 \mathrm{hsa}$ & $7 \mathrm{hsa}$ \\
\hline UO & $0,8520 a$ & $0,0785 a b$ & $0,0005 \mathrm{a}$ & $0,0060 \mathrm{a}$ \\
\hline U1 & $0,2830 a$ & $0,1705 a$ & $0,0010 a$ & $0,0045 a b$ \\
\hline U2 & $0,2775 \mathrm{a}$ & $0,1010 a b$ & $0,0005 a$ & $0,0035 b c$ \\
\hline U3 & $0,2860 \mathrm{a}$ & $0,0565 \mathrm{~b}$ & $0,0000 \mathrm{a}$ & $0,0010 \mathrm{c}$ \\
\hline U4 & $0,2040 \mathrm{a}$ & $0,0360 \mathrm{~b}$ & $0,0000 \mathrm{a}$ & $0,0025 b c$ \\
\hline U5 & $0,2535 a$ & $0,0375 \mathrm{~b}$ & $0,0000 \mathrm{a}$ & $0,0020 b c$ \\
\hline U6 & $0,2705 a$ & $0,0130 \mathrm{~b}$ & $0,0000 \mathrm{a}$ & $0,0010 \mathrm{c}$ \\
\hline
\end{tabular}

Angka dalam lajur diikuti huruf sama tidak berbeda nyata pada taraf 5\% menurut uji DMRT, hsa $=$ hari setelah aplikasi insektisida, hst $=$ hari setelah tumbuh

Keterangan : $\mathrm{U} 0=$ tanpa arang aktif, $\mathrm{U} 1=$ arang aktif tempurung kelapa U2 = arang aktif tongkol jagung, U3 = arang aktif tempurung kelapa diperkaya mikroba konsorsia, , U4 = arang aktif tongkol jagung diperkaya mikroba konsorsia U5 = arang aktif tempurung kelapa + mikroba U6 = arang aktif tongkol jagung + mikroba konsorsia

insektisida lindan dan aldrin dalam tanaman yang diberi arang aktif dari tempurung kelapa adalah lebih tinggi daripada arang aktif dari tongkol jagung.

Biomassa tanaman sawi terdeteksi mengandung pestisida lindan dalam kadar lebih tinggi $0,1 \mathrm{ppm}$. Batas maksimum residu aldrin dan lindan untuk tanaman sawi masing-masing sebesar $0,1 \mathrm{ppm}$ dan $0,5 \mathrm{ppm}$ (7). Arang aktif efektif menjerap senyawa- senyawa pestisida POPs misalnya senyawa pestisida terklorinasi (aldrin, DDT, PCB, dsb.) (10), namun bilamana kapasitas jerap pada permukaan arang aktif terhadap pestisida POPs telah jenuh maka senyawa POPs terlarut dalam larutan tanah yang tidak terjerap akan hilang melalui volatilisasi dan perlindian dan diserap akar tanaman dan ditranslokasikan ke jaringan tanaman, sehingga tanaman terdeteksi mengandung pestisida POPs tinggi.

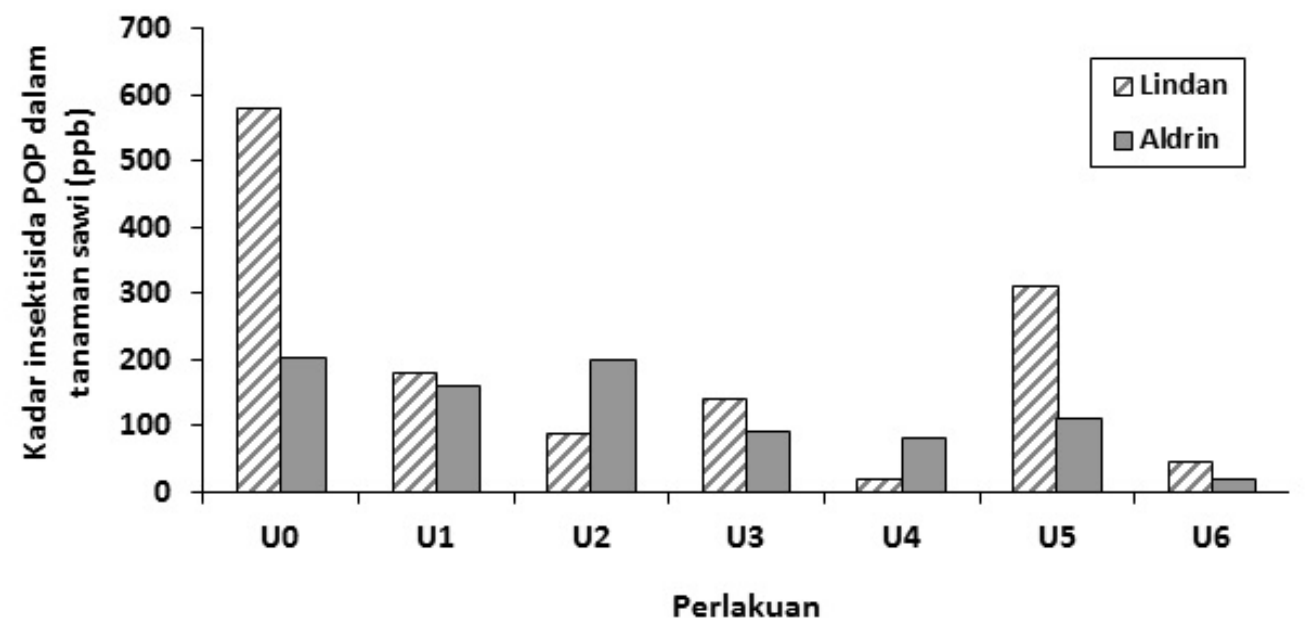

Gambar 2. Kandungan residu lindan dan aldrin dalam tanaman sawi pada beberapa perlakuan arang aktif di lahan sayuran Magelang pada MH 2010.

(U0 = tanpa arang aktif, $\mathrm{U} 1$ = arang aktif tempurung kelapa U2 = arang aktif tongkol jagung, U3 = arang aktif tempurung kelapa diperkaya mikroba konsorsia, , U4 = arang aktif tongkol jagung diperkaya mikroba konsorsia $\mathrm{U} 5$ = arang aktif tempurung kelapa + mikroba U6 = arang aktif tongkol jagung + mikroba konsorsia) 


\section{Pertumbuhan dan Hasil Tanaman Sawi}

Pemberian arang aktif nyata mempengaruhi tinggi tanaman dan lebar kanopi tanaman sawi saat 7 hari setelah aplikasi insektisida, tetapi tidak nyata mempengaruhi jumlah daunnya (Tabel 4). Pada awal fase pembentukan crop, arang aktif nyata mempengaruhi jumlah daun $(\mathrm{p}<0,5)$, tinggi tanaman $(\mathrm{p}<0,0001)$, dan lebar kanopi $(p<0,0004)$. Perlakuan U2 dan U3 memberikan pertumbuhan tanaman terbaik saat 7 hsa dan saat 21 hari setelah tumbuh (hst). Arang aktif dari tongkol jagung efektif memberikan hasil pertumbuhan tanaman tertinggi, namun bilamana diperkaya dengan mikroba konsorsia memberikan pertumbuhan tanaman lebih rendah daripada tidak diperkaya dengan mikroba konsorsia, sedangkan penggunaan urea berlapis arang aktif tempurung kelapa diperkaya dengan mikroba meningkatkan tinggi tanaman dan lebar kanopi saat 7 hari setelah aplikasi dan awal permbentukan crop.

Hasil biomassa kering sayuran sawi nyata dipengaruhi oleh perlakuan arang aktif $(\mathrm{p}<$ 0.0132). Hasil biomassa rendah ditunjukkan pada perlakuan U0, U4, U6 dengan hasil biomassa masing-masing 0,$86 ; 0,84 ; 0,77$ t/ha. Perlakuan U1, U2, U3, U5 masingmasing dapat menghasilkan biomassa kering sebesar 1,24; 1,49; 1,38; 1,49 t/ha (Gambar 4). Perlakuan arang aktif tempurung kelapa yang diperkaya mikroba konsorsia meningkatkan biomassa kering sawi.

Tabel 4. Kondisi pertumbuhan tanaman sawi saat 7 hari setelah aplikasi pupuk dan saat awal pembentukan crop, MH 2010

\begin{tabular}{|c|c|c|c|c|c|c|}
\hline \multirow{2}{*}{ Perlakuan } & \multicolumn{2}{|c|}{ Jumlah daun } & \multicolumn{2}{|c|}{ Tinggi tanaman (cm) } & \multicolumn{2}{c|}{ Lebar kanopi (cm) } \\
\cline { 2 - 7 } & 7 hsa & 21 hst & 7 hsa & 21 hst & 7 hsa & 21 hst \\
\hline U0 & $3,4 \mathrm{a}$ & $6,4 \mathrm{~b}$ & $4,8 \mathrm{~b}$ & $10,5 \mathrm{bc}$ & $6,4 \mathrm{ab}$ & $17,2 \mathrm{abc}$ \\
U1 & $3,1 \mathrm{a}$ & $7,1 \mathrm{ab}$ & $4,3 \mathrm{c}$ & $10,3 \mathrm{bc}$ & $5,3 \mathrm{~b}$ & $17,1 \mathrm{abc}$ \\
U2 & $3,1 \mathrm{a}$ & $8,2 \mathrm{a}$ & $5,6 \mathrm{a}$ & $12,9 \mathrm{a}$ & $6,4 \mathrm{ab}$ & $21,5 \mathrm{a}$ \\
U3 & $3,6 \mathrm{a}$ & $7,5 \mathrm{ab}$ & $5,2 \mathrm{ab}$ & $11,9 \mathrm{ab}$ & $6,9 \mathrm{a}$ & $18,8 \mathrm{ab}$ \\
U4 & $3,2 \mathrm{a}$ & $6,9 \mathrm{ab}$ & $4,2 \mathrm{c}$ & $9,1 \mathrm{~cd}$ & $6,0 \mathrm{ab}$ & $14,0 \mathrm{bcd}$ \\
U5 & $3,2 \mathrm{a}$ & $6,2 \mathrm{~b}$ & $4,2 \mathrm{c}$ & $8,8 \mathrm{~cd}$ & $5,9 \mathrm{ab}$ & $12,5 \mathrm{~cd}$ \\
U6 & $3,0 \mathrm{a}$ & 6,3 b & $4,7 \mathrm{~b}$ & $7,8 \mathrm{~d}$ & $5,4 \mathrm{~b}$ & $11,9 \mathrm{~d}$ \\
\hline
\end{tabular}

Angka dalam lajur diikuti huruf sama tidak berbeda nyata pada taraf $5 \%$ menurut uji DMRT, hsa $=$ hari setelah aplikasi insektisida, hst $=$ hari setelah tumbuh

Keterangan : $\mathrm{U} 0=$ tanpa arang aktif, $\mathrm{U} 1=$ arang aktif tempurung kelapa U2 = arang aktif tongkol jagung, U3 = arang aktif tempurung kelapa diperkaya mikroba konsorsia, , U4 = arang aktif tongkol jagung diperkaya mikroba konsorsia $\mathrm{U} 5$ = arang aktif tempurung kelapa + mikroba U6 = arang aktif tongkol jagung + mikroba konsorsia 


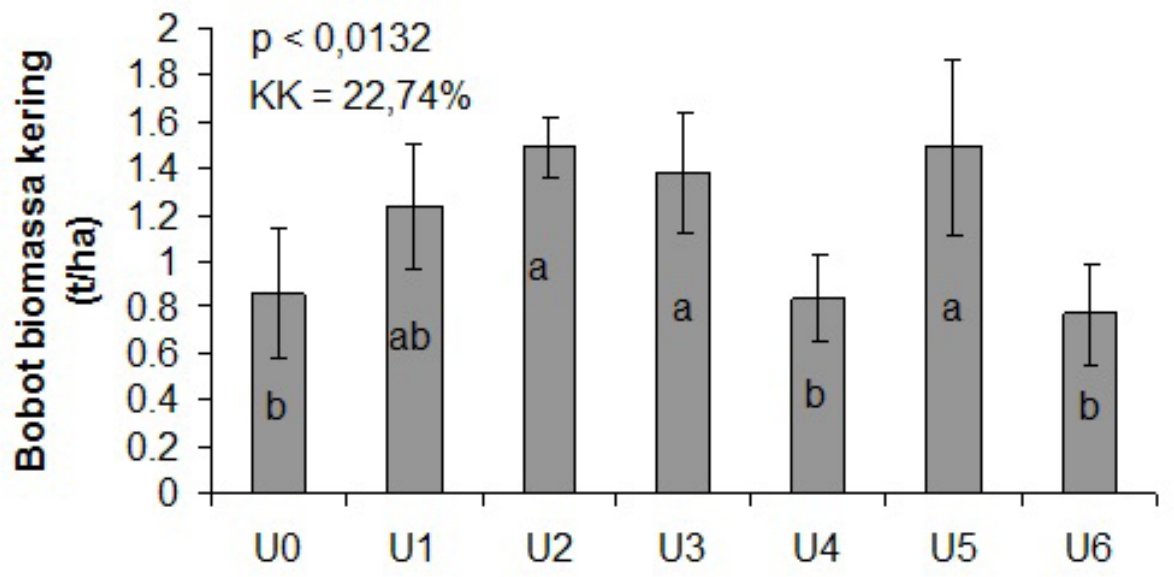

Gambar 4. Hasil biomassa sawi kering yang diberi perlakuan arang aktif di Magelang, MH 2010. Bar diikuti huruf sama berarti tidak berbeda nyata menurut uji jarak ganda Duncan 5\% (U0 = tanpa arang aktif, $\mathrm{U} 1=$ arang aktif tempurung kelapa $\mathrm{U} 2=$ arang aktif tongkol jagung, U3 = arang aktif tempurung kelapa diperkaya mikroba konsorsia, , U4 $=$ arang aktif tongkol jagung diperkaya mikroba konsorsia U5 = arang aktif tempurung kelapa + mikroba U6 = arang aktif tongkol jagung + mikroba konsorsia)

\section{KESIMPULAN}

1. Arang aktif efektif menurunkan residu lindan dan aldrin dalam tanah hingga lebih dari $50 \%$ saat 7 hari setelah aplikasi insektisida pada tanaman sawi.

2. Arang aktif yang diperkaya mikroba konsorsia cenderung menurunkan residu lindan dan aldrin lebih tinggi daripada arang aktif tanpa diperkaya mikroba konsorsia.

3. Arang aktif tongkol jagung dengan inokulasi mikroba konsorsia lebih efektif menurunkan kadar lindan dan aldrin dalam tanaman.

4. Pemberian arang aktif cenderung memberikan hasil biomassa tanaman sawi lebih tinggi daripada tanpa arang aktif.

5. Peranan mikroba konsorsia mampu meningkatkan efektivitas arang aktif dari tongkol jagung dalam menurunkan kadar lindan dan aldrin dalam tanaman.

\section{UCAPAN TERIMA KASIH}

Ucapan terima kasih disampaikan kepada Kementerian Riset dan Teknologi yang telah menyediakan dana penelitian dalam Program Insentip Ristek Tahun 2010. Penghargaan yang tulus disampaikan kepada para teknisi (Slamet Rianto, Nanang, Cahyadi, A.Md, Sarwoto, BSc. dan Aji M. Tohir) dan laboran di Laboratorium Balai Penelitian Lingkungan Pertanian yang telah membantu dalam pelaksanaan percobaan lapang dan analisis di laboratorium dan Kantor Dinas terkait di Magelang.

\section{DAFTAR PUSTAKA}

(1) Choma, J., \& M. Jaroniec. 2006. Characterization of nanoporous carbons by using gas adsorption isotherms. p. 107-158 in Bandosz, T.J. (ed.). Activated Carbon Surfaces in Environmental Remediation. Elsevier. 
(2) Takagi, K., R. Kataoka, \& K. Yamazaki. 2011. Recent technology on bio-remediation of POPs and persistent pesticides. JARQ 45(2) : 129-136.

(3) Arbeli, Z., \& C.L. Fuentes. 2007. Accelerated biodegradation of pesticides : an overview of the phenomenon, its basis and possible solution, and a discussion on the tropical dimension. Crop Protection $26: 1733-1746$.

(4) Diez, M.C. 2010. Biological aspects involved in the degradation of organic pollutants. J. Soil Sci. Plant Nutr. 10(3) : 244-267.

(5) Nawaz, K., K. Hussain, N. Choudary, A. Majeed, U. Ilyas, A. Ghani, F. Lin, K. Ali, S. Afghan, G. Raza, and M.I. Lashari. 2011. Eco-friendly role of biodegradation against agricultural pesticides hazards. African J. Microbiol. Res. 5(3) : 177-183.

(6) Ohsawa, K., S. Hartati, S. Nugrahati, H. Sastrohamidjoyo, K. Untung, N. Arya. K. Sumiartha, \& S. Kuwatsuka. 1985. Residue analysis of organochlorin and organophosphorus pesticides in soil, water and vegetables from central Java and Bali, ecol./impact of IPM in Indoensia. p. 59-70.
(7) SNI. 2008. SNI 7313 : 2008. Batas maksimum residu pestisida pada hasil pertanian. Badan Standardisasi Nasional.

(8) Koumanova, B. 2008. Distribution of POPs in aquatic ecosystems and processes for their removal. pp. 239-249 in Mehmethi, E., \& B. Koumanova (eds.). The Fate of Persistent Organic Pollutants in The Environment. Springer, Netherlands.

(9) Cornejo, J., \& R. Celis. 2008. Remediation of contaminanted soils and water with organic chemicals by means of natural, anionic and organic clays. pp. 355-368 in Mehmethi, E., $\&$ B. Koumanova (eds.). The Fate of Persistent Organic Pollutants in The Environment. Springer, Netherlands.

(10) Peng, R.H., A.S. Xiong, Y. Xue, X.Y. Fu, F. Gao, W. Zhao, Y.S. Tian, \& Q.H. Yao. 2008. Microbial biodegradation of polyaromatic hydrocarbons. FEMS Microbiology Reviews 32(6) : 927955. 